\title{
Learning Through Play at School - A Framework for Policy and Practice
}

\author{
Rachel Parker ${ }^{1 *}$, Bo Stjerne Thomsen ${ }^{2 \dagger}$ and Amy Berry ${ }^{1 \dagger}$ \\ ${ }^{1}$ Education and Development Research Program, Australian Council for Educational Research, Camberwell, VIC, Australia, \\ ${ }^{2}$ LEGO Foundation, Billund, Denmark
}

Learning through play has emerged as an important strategy to promote student engagement, inclusion, and holistic skills development beyond the preschool years. Policy makers, researchers and educators have promoted the notion that learning though play is developmentally appropriate-as it leverages school-age children's innate curiosity while easing the often difficult transition from preschool to school. However,

OPEN ACCESS

Edited by:

Cheryl J. Craig,

Texas A\&M University, United States

Reviewed by:

Joseph Samuel Backman, Alpine School District, United States

Renee Moran,

East Tennessee State University,

United States

Feyza Tantekin Erden,

Middle East Technical University,

Turkey

${ }^{*}$ Correspondence:

Rachel Parker

rachel.parker@acer.org

†These authors have contributed equally to this work and share first authorship

Specialty section: This article was submitted to

Teacher Education, a section of the journal

Frontiers in Education

Received: 02 August 2021

Accepted: 27 January 2022

Published: 17 February 2022

Citation:

Parker R, Thomsen BS and Berry A (2022) Learning Through Play at School - A Framework for Policy and Practice. Front. Educ. 7:751801.

doi: 10.3389/feduc.2022.751801 there is a dearth of evidence and practical guidance on how learning through play can be employed effectively in the formal school context, and the conditions that support success. This paper addresses the disconnect between policy, research and practice by presenting a range of empirical studies across a number of well-known pedagogies. These studies describe how children can foster cognitive, social, emotional, creative and physical skills through active engagement in learning that is experienced as joyful, meaningful, socially interactive, actively engaging and iterative. The authors propose an expanded definition for learning through play at school based on the science of learning, and summarize key findings from international studies on the impact of children's learning through play. They identify four key challenges that underpin the considerable gap between education policy and practice, and propose a useful framework that addresses these challenges via a common language and structure to implement learning through play.

Keywords: education policy, elementary, primary school, framework, learning through play, pedagogy, teaching

\section{LEARNING THROUGH PLAY AND GLOBAL EDUCATION POLICY AND PRACTICE}

Our understanding that children learn through the natural inquiry process of play has a strong basis in research. Anthropologists, developmental psychologists and neuroscientists have studied and documented this phenomenon extensively (Whitebread et al., 2012). More than a century ago, Dewey (1910) made the connection between children's natural experimentation in play and the scientific inquiry process. Vygotsky (1978) noted that play is hugely influential on child development in fostering speech development, cognitive processing, self-awareness and selfregulation. Neuroscientists have discovered that the prefrontal cortex of the brain is refined by play, and play stimulates the production of a protein responsible for the differentiation and growth of new neurons and synapses (Gordon et al., 2003). Conversely, play deprivation negatively affects brain development and problem-solving skills (Pellis et al., 2014). Play interventions are 
widely used as a treatment for children who struggle to develop socio-emotional skills including establishing positive peer relationships (Fantuzzo and Hampton, 2000).

The perennial interest in these ideas is reflected in current global education policy and research. Increasing numbers of international studies now measure holistic skills, such as socio-emotional learning, creative thinking, global competence, innovation, and physical development (UNESCO, 2016; Vincent-Lancrin et al., 2017; OECD, 2018). Intergovernmental organizations such as the United Nations recognize that the skills, knowledge and values children need to thrive in the future far exceed proficiency in traditional learning areas such as literacy and numeracy (UNESCO, n.d.). As technology advances and workplaces evolve, governments and education systems are realizing that a more holistic view of education and learning is required, in order to best equip children to thrive, and ultimately, reach their full potential as adults in society (Foundation for Young Australians [FYA], 2017; Ernst and Reynolds, 2021).

Understanding teaching practice across the early years is integral to advancing these goals. As global standards and outcomes for learning expand to include holistic skills, curricula have become more crowded and teachers' roles ever more demanding (Darling-Hammond, 2006). Which pedagogical approaches might most effectively achieve our expanded goals for education? Research points to learning through play as a promising pedagogy that is correspondingly expansive in its aims and outcomes for learning (Marbina et al., 2011).

There are, however, significant challenges to embedding learning through play in practice. The first hurdle is semantic. Play is a complex phenomenon that is difficult to define (Mastrangelo, 2009; McAloney and Stagnitti, 2009; Whitebread et al., 2012; Zosh et al., 2018). This presents a challenge-that the very basis for learning is a contested notion. Further, the lay definition of play is to "engage in an activity for enjoyment or recreation rather than a serious purpose" (Oxford University Press, 2020). Play's reputation as a non-serious/non-work-related pursuit is problematic, especially at school, where teachers are accustomed to more rigid curricula structures and attainment targets (Martlew et al., 2011). The play/learning dichotomy trivializes play as an activity for recess only, or a reward for when the "real work" of learning is done (Whitebread et al., 2012). When we dichotomize play and learning (or play and work) we negate the view that play itself is educational and children can learn through play (Wing, 1995; Nilsson et al., 2018). This severely curtails its potential as an effective classroom-based pedagogy.

The second major impediment to implementing learning though play is the perception that it is a pedagogy native to preschool and incongruous to primary school learning. Some researchers have used synonymous terms, for example "active learning" in order to achieve legitimacy at school (Martlew et al., 2011; Smith, 2015). While learning through play is associated with high quality early childhood education practice and research (Wall et al., 2015; Nilsson et al., 2018), and international policy standards define early childhood as the years from zero to eight (Irwin et al., 2007), studies of learning through play in school for children beyond age five are limited (Howard, 2010; Jay and Knaus, 2018). Low uptake in school is likely due to differing perceptions of play and learning (Smith, 2015) and the competing demands and constraints of the preschool and school learning environments (Nicholson and Hendry, 2020). Other barriers to implementing learning through play include assessment and accountability. There is a lack of established instruments and consistent approaches to measuring the gains associated with playful learning conditions (McAloney and Stagnitti, 2009; DeLuca and Hughes, 2014). Further, in a misguided effort to increase school readiness, some education systems are introducing basic reading and mathematics skills earlier in preschool at the expense of whole-child development through playful pedagogies (Miller and Almon, 2009; AlleeHerndon and Roberts, 2020). The notion of readiness here is hierarchical, where the lower level serves the needs of the higher (Moss, 2013), and is reflected across the system, reinforcing the equation that a higher level = higher importance, status, and stakes .

\section{INCLUSIONS AND KEY TERMS}

This article focuses on the pedagogy "learning through play," also referred to as play-based learning (Barblett, 2010), playful learning (Fisher et al., 2010), and purposeful play (AlleeHerndon and Roberts, 2020). We do not attempt to define "play" distinctly, nor situate play in educational contexts as a standalone phenomenon. We refer to ways that learning through play occurs, for example as child-led, adult-guided or adult-led as "facilitation" given they point to the roles adults and children occupy during learning through play experiences.

\section{AN EXPANDED DEFINITION OF LEARNING THROUGH PLAY}

A useful definition for learning through play should incorporate contemporary research about children's experiences of play, address the role of the child and adult, and the desired learning outcomes of the approach. Researchers have found five characteristics that embody educational play experiences: those that that are meaningful, actively engaging, joyful, iterative, and socially interactive (Zosh et al., 2017). Further, play has been recently redefined as a spectrum or continuum involving child-directed activity, and also adult-guided and adult-directed activity (Weisberg et al., 2013; Pyle and Danniels, 2016), bringing clarity to the adult and child's roles in facilitating learning through play. The spectrum acknowledges that learning through play, like engagement, is "not a dichotomous condition. . it can be partial, fleeting and superficial" (Hunzicker and Lukowiak, 2012. p. 101). A nuanced understanding of the different types of play facilitation can help teachers to meaningfully reflect on their practice by identifying the types and balance within the context and purpose of a lesson, and the impact of these facilitation approaches on student experience and learning outcomes (Zosh et al., 2018). In this paper, these ideas are presented alongside other key features of a framework for learning through play at school. 
Henceforth, we define learning through play as when:

1. Children develop holistic skills by interacting with people, objects and representations (Department of Education and Training, 2016) in actively engaging, joyful, iterative, meaningful and socially interactive experiences (Zosh et al., 2017).

2. Experiences are designed and facilitated to make effective use of available resources and integrate child-led, teacherguided, and teacher-led opportunities (Marbina et al., 2011).

This article presents an evidence-based outlook for learning through play at school. It summarizes five key conclusions from Parker and Thomsen's (2019) scoping review of evidence of the role and impact of learning through play at school as the basis for a contextually relevant quality framework. It describes four key challenges to connecting policy and practice that the framework attempts to address. It presents the framework and its essential dimensions: the child's experience, the facilitator's role, the activity design, and the outcomes of learning. It includes a discussion on the utility of the framework and future directions for development.

\section{CONCLUSIONS FROM LEARNING THROUGH PLAY AT SCHOOL}

To address the dearth of evidence on the role and impact of learning through play beyond preschool, Parker and Thomsen (2019) completed a scoping review framed by the research question "how has learning through play been applied in formal schooling, and what has been the impact on children's holistic skills" (p. 7). The review sought to understand current practice in schools around the world, and the extent to which learning through play belongs, and is beneficial, in formal education settings.

The research question was explored through multiple lenses. First, play was broadly defined using the five characteristics proposed by Zosh et al. (2017). Parker and Thomsen (2019) reviewed a range of literature $(n=124)$ across creativity, play and the science of learning and found that playful experiences lead to deeper learning when they are joyful, actively engaging, meaningful, iterative, and socially interactive. Deeper learning was described as learning that was meaningful, through making connections with prior knowledge (Sinnema et al., 2011) and learning that is reinforced through different contexts and activities (Marbina et al., 2011). The scoping review defined learning in the broadest sense, as the development of cognitive, social, emotional, creative, and physical skills, as consistent with the literature regarding whole child development in the early years (Fisher et al., 2010). Through these dual lenses, the authors located and analyzed literature regarding play and learning at school (see Figure 1).

The applicable cohort was defined as learners aged 6-12, and almost half of the studies $(n=61)$ examined compared playful and traditional approaches using intervention or quasi-experimental methodologies. These were deemed most relevant as the research question focused on the impact, as in the learning outcomes, associated with learning through play.

Parker and Thomsen (2019) found that pedagogies that align closely with learning through play are those that arise from the same constructivist learning theories, namely active learning, collaborative and cooperative learning, experiential learning, guided discovery learning, inquiry-based learning, problem-based learning, project-based learning, and Montessori education. These approaches are facilitated in a way that integrates child-directed, teacher-guided and teacher led-learning (Marbina et al., 2011). Accordingly, Parker and Thomsen (2019) used the term "playful integrated pedagogies" to collectively describe these approaches. Herein we have abridged the term to "playful pedagogies for ease of expression, while retaining the key word 'play'."

Parker and Thomsen's (2019) review enhanced understanding of the scope of learning through play at school by offering five broad conclusions:

\section{Finding 1: Learning Through Play Has a Place at School}

When learning through play was defined as joyful, meaningful, iterative, socially interactive and actively engaging experiences, focused on fostering cognitive, social, emotional, creative and physical skills, it was found to be both relevant and widely used in primary school. Each of the characteristics of play, and the focus on holistic skills development, were explicit in a range of impact studies of active learning, collaborative and cooperative learning, experiential learning, guided discovery learning, inquiry-based learning, problem-based learning, project-based learning, and Montessori education. Parker and Thomsen (2019) unpacked the ways in which each of these approaches aligned with the definition of learning through play, for example, how they involved iteration to explore new concepts or ideas, or how they involved interaction with peers to foster socio-emotional learning. This finding is important as it suggests that schools can avoid "change fatigue" (Dilkes et al., 2014) and start from where they are to refine and enhance implementation, rather than propose a completely new learning paradigm that requires significant systemic reform. Further, the sheer prevalence of these approaches across countries and systems suggests a strong and supportive base upon which to build improvements in quality.

\section{Finding 2: Playful Pedagogies Can Be Highly Effective}

There is abundant evidence of what works in education (Hattie, 2009). However, there is often a lack of agreement about what the "what" actually is. Discovery learning, problem based learning, inquiry learning and experiential learning have been framed wholly as minimally guided (Kirschner et al., 2006; Dinham, 2017), extensively guided (Hmelo-Silver et al., 2007), or as a spectrum where some activities are guided by the teacher and some by the student (Furtak et al., 2016). In some instances authors do not clearly define the pedagogy at all, rendering comparisons fruitless (Cattaneo, 2017). Parker and Thomsen (2019) attempted to address this issue by defining each approach 


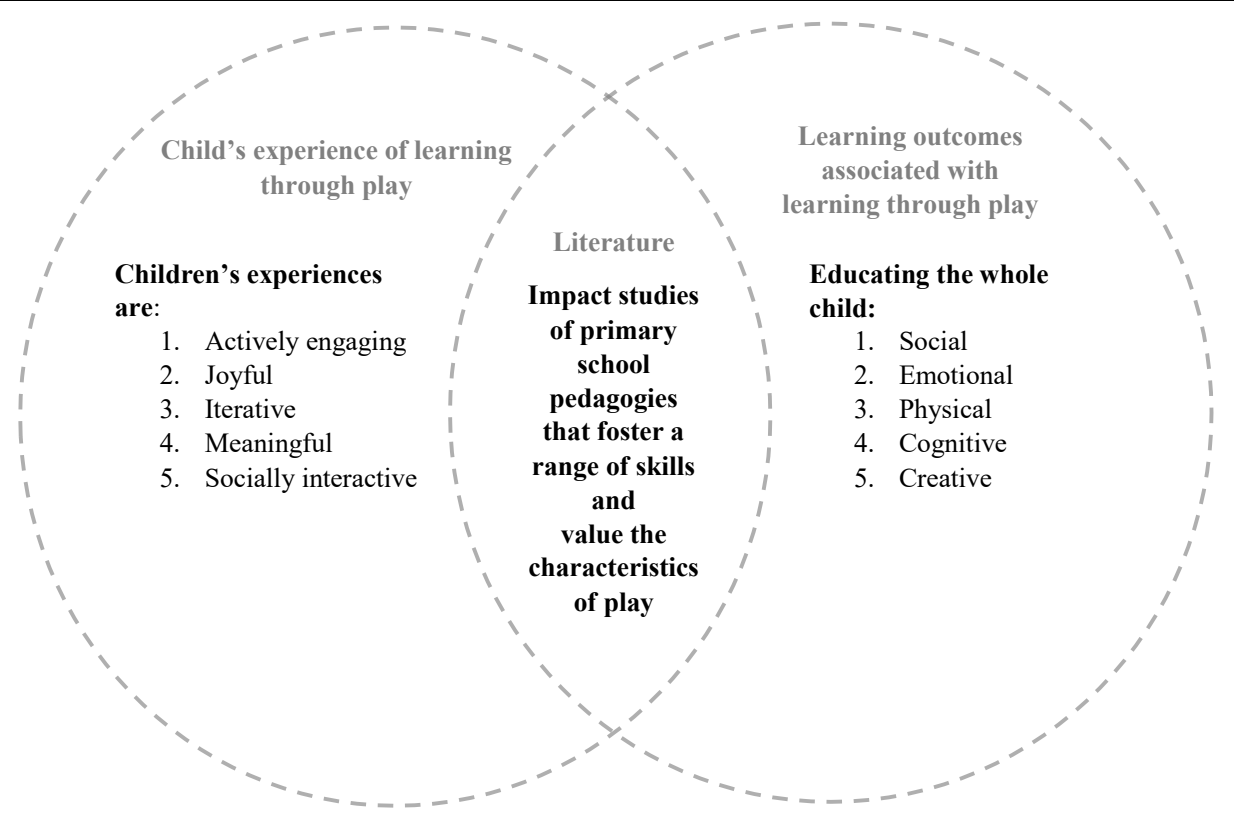

FIGURE 1 | Conceptualization of learning through play for literature analysis.

and describing the impact from peer reviewed empirical studies, making the review valuable to educators who use, plan to use, or plan to refine their practice regarding playful pedagogies. For these educators it is helpful to know what we mean by playful pedagogies, that they can be effective, and that they are effective under certain conditions (and what these conditions are, see Finding 4).

Evidence reviewed by Parker and Thomsen (2019) suggested that playful pedagogies can be more effective in fostering social, emotional, physical, cognitive and creative skills than "traditional" or more "highly guided" pedagogical approaches used in the primary school classroom. Studies measured the achievement and/or growth demonstrated by students learning under a more playful condition, with the results of students learning under a less-playful condition. The types of positive impact presented included: learning gains sustained over time (DeanJr., and Kuhn, 2007); skills transfer to novel problems (Purpura et al., 2016); more accurate recall of knowledge gained (Castano, 2008); deeper understanding of concepts (Burke and Williams, 2012); and making better connections between concepts (Castano, 2008).

\section{Finding 3: Effectiveness Is Underpinned by Key Enabling Factors}

Parker and Thomsen (2019) recognized that it was not sufficient to simply make the case for learning through play at school via playful pedagogies, and present a range of impact evidence. By presenting a range of implementation quality factors, they suggest that framing, context, implementation processes and fidelity play key roles when considering success; no single pedagogical approach is inherently effective. The factors that underpin success are essential to understand in order to replicate positive results.
Parker and Thomsen (2019) summarized a series of key success factors from the literature as follows:

- Student factors: Learners bring prior experiences, skills and knowledge to the classroom that may impede or support the implementation of strategies that, for example, require strong oral language, or decision-making skills (Barron and Darling-Hammond, 2010; Tan and Chapman, 2016).

- Facilitation: Teachers understood and used essential strategies, understood their learners, scaffolded learning, adjusted their approach to meet the needs of their learners, and acted as learners' mentors or guides. Teachers knew and understood what playful pedagogies are and are not, and they had sufficient subject matter knowledge to guide investigations (Marbina et al., 2011; Block et al., 2012).

- Design: Teachers designed activities that built on learners' experiences, knowledge and learning needs; they included long and short-term goals, were evidencebased, well planned and structured, combined facilitation types, and fostered higher order thinking and skills (Block et al., 2012).

- Learning outcomes: Effective playful pedagogies covered depth not breadth, included multidimensional and integrated assessment, and allowed for some flexibility in implementation (Schwartz et al., 2009).

- School, system and community: Supportive leadership and a whole of school approach to implementing playful pedagogies, including leadership support, planning, scheduling, time, physical space and resources are vital for success. When parents are actively engaged, and hold beliefs and values that align with playful approaches, success is more likely (Davison et al., 2008; Jay and Knaus, 2018). 
These key success factors informed the framework components and guiding questions below.

\section{Finding 4: Effective Playful Pedagogies Combined Facilitation Types}

For each of the eight playful pedagogies included in the scoping review, Parker and Thomsen (2019) presented a definition, its alignment with the characteristics of play, evidence of impact, and enabling factors. While noting that they are often used in combination (Cattaneo, 2017), for example “experiential problem-based collaborative learning," presenting playful pedagogies distinctly allowed the reader to identify the similarities across approaches, including those related to facilitation.

In distilling the evidence presented about each of the playful pedagogies regarding the teachers' role, the techniques or methods they use, and the knowledge they possess, a common theme emerged. Teachers who use playful pedagogies effectively combined facilitation types. While they were primarily described as a guide, facilitator, or mentor (Di Mauro and Furman, 2016), their lessons were also well planned and structured (Purpura et al., 2016) and often framed by discussions about prior knowledge of the topic at the outset (Hotulainen et al., 2016) to prepare minds for learning (Bruner, 1961) and included opportunities for reflection in groups (Johnson and Johnson, 1991). Classroom rules were co-created with learners (Kaput, 2018) enabling learners the freedom to act independently (Block et al., 2012). Featured prominently in the evidence was scaffolding (Hmelo-Silver et al., 2007), described as posing openended questions (Haßler et al., 2015), encouraging knowledge sharing, monitoring discussions, and providing hints and guiding questions (Hushman and Marley, 2015), coaching, feedback, worked examples, and modeling (Alfieri et al., 2011). Teachers provided opportunities for hands-on learning (McBride et al., 2016) exploration of ideas and materials, and fostered agency by encouraging students to make decisions about their learning (Fullan and Langworthy, 2014) such as how an activity is performed or when it is complete (Laevers, 2000). There was clear evidence of teacher direction, teacher guidance, and childdirected activity in school classrooms that use playful pedagogies effectively. This description echoes Zosh et al. (2018) who described the range of what they called "play types," all distinctly valuable within a spectrum of play, adding nuance to the often binary discourse around play and learning, and Marbina et al. (2011) description of purposeful integration of child-led, teacher-guided, and teacher-led learning as best practice in early childhood education settings including primary school.

\section{Finding 5: Agency Is Central to Playful Pedagogies}

A number of studies $(n=10)$ reviewed by Parker and Thomsen (2019) included the concepts of learner choice and agency regarding learning content and process, as essential features of playful pedagogies. Fostering independent and autonomous learners who are skilled at decision-making is described as a goal for learning via playful pedagogies. When learners have the opportunity to practice making meaningful choices about their project or inquiry topic and how it is undertaken, in conjunction with teacher support and facilitation, learners demonstrate greater engagement, motivation and positive disposition toward learning. Agency and autonomy in learning are associated with fostering ownership of learning (Fullan and Langworthy, 2014), empowered and self-actualized learners, and the development of executive function, problem solving and planning skills.

Parker and Thomsen (2019) tabulated the features of effective and highly agentic learning environments and found that they were characterized as those where learners:

- Make authentic and genuine choices about their learning (Verner and Lay, 2010; Hixson et al., 2012; Fullan and Langworthy, 2014).

- Ask teachers questions and offer opinions or reflections (Smith, 2015).

- Have freedom of movement within the classroom to interact with teachers, peers and materials as appropriate (Smith, 2015).

- Have time to overcome "false starts" and "failures" when task choices need revisiting or groups reformed (Tan and Chapman, 2016).

- Make authentic and genuine choices in combination with other instructional strategies (Tan and Chapman, 2016).

- Are guided by teachers to make decisions about learning (Smith, 2015).

- Are guided by teachers to make choices involving carefully planned, managed and rigorously assessed tasks (Hixson et al., 2012).

- Learn choice-making skills gradually and experientially (Fullan and Langworthy, 2014).

\section{CONNECTING POLICY AND PRACTICE}

Increasingly, teachers are positioned as agents of change, responsible for putting policy into practice (van der Heijden et al., 2018). Their individual beliefs, skills, knowledge and attitudes act as mediators between what is written in policy and what is enacted in the classroom-therefore translation is an "uncertain process" (Priestley, 2011, p. 2). In addition, it has been argued elsewhere that reform and innovation do not travel well, whether across time periods or across contexts (Watkins and Biggs, 2001; Hargreaves, 2010). Despite growing support for learning through play at a global policy level, and evidence that there are a number of playful pedagogies that share the characteristics of learning through play, implementation in the primary school classroom presents a series of challenges.

\section{Challenge 1: A Lack of Continuity Between Preschool and School Pedagogies}

Globally recognized definitions of early childhood span the years zero to eight (World Health Organization [WHO], 2020), meaning that early childhood education straddles the two distinct learning contexts of preschool and school. The pedagogies 
employed in these two settings are often starkly different, particularly when comparing preschool and the early primary years beyond year one (Woodhead and Moss, 2007). In recent years, there has been a call for more didactic learning in preschool, referred to as the "pushdown curriculum" (Miller and Almon, 2009). Others argue that the principles and approaches of high-quality early learning should be "pushed up" into school, acknowledging that the transition process is multidirectional and the responsibility of all early childhood stakeholders, to ensure that schools are ready for children (OECD, 2017). Adding to the challenge of implementing learning through play within the school context, most learning through play policy and research focuses largely on pre-school rather than primary school settings (Bubikova-Moan et al., 2019). Arguably, the two contexts bring with them important differences that must be considered when attempting to implement instructional practices and pedagogical approaches described at the policy level (Allee-Herndon and Roberts, 2020). Such division amongst the different communities of practice around the place for play in learning, and disregard for the different contexts of early childhood education, does not help to move policy initiatives forward (Nicholson and Hendry, 2020).

\section{Challenge 2: A Lack of Clarity Around the Definition and Role of Learning Through Play at School}

Along with issues of context, there is a persistent lack of consensus and clarity about what we mean by learning through play. Indeed, the terms play and learning may be so familiar that we run the risk of believing they do not need to be defined under the assumption that a common understanding already exists amongst the education community. The importance of speaking a common language around any reform or policy initiative cannot be underestimated (Hill, 2006). A common language ensures that all parties understand the intended change in the same way (policy makers, system leaders, school-based educators, community). This can be described as "collective sensemaking" or the "creation of coherent and shared explanations for "how we do things around here"' (Louis, 2010, p. 18). Without clear and precise definitions of these terms, it remains difficult to know if contributors to the debate are talking about the same thing or if the conceptions held by different stakeholders are congruent. Furthermore, without a clear understanding of what implementation looks like at varying levels of quality, it is hard to reliably evaluate the effectiveness of any attempts to implement policy initiatives around playful learning in any meaningful way.

\section{Challenge 3: A Lack of Consensus About the Intended Outcomes of Education}

Any attempt to conceptualize learning through play must consider not only the "play" element but also what quality learning looks like and what outcomes of learning are expected. The current push for evidence-based or evidence-informed practice within the field of education hinges on the ability to generate and access evidence of the effectiveness of an instructional practice in facilitating student outcomes such as academic achievement or growth (Pyle et al., 2017). It is fair to say that there is a tendency to favor outcomes such as literacy and numeracy development, where there are well-established means of assessing student progress, rather than the broader skills associated with learning through play (Pyle et al., 2020). This may explain, in part, the persistent questions about the effectiveness of playful pedagogies (Cheng et al., 2008), and may result in uncertainty on the part of educators who wish to integrate this approach in the classroom (Smith, 2015). Even amongst proponents of learning through play, there is debate over whether play is essential for learning and development or one of many paths to learning and development (the notion of equifinality) (Roskos et al., 2010). Roskos et al. (2010) argued that some may believe play is nice but non-essential for learning and development, while outwardly espousing a more favorable view of play in accordance with prevailing socially acceptable ideas. That is, it is not acceptable to speak in a negative way about play, so any such views must remain hidden. Roskos et al. (2010, p. 57) go on to argue that while the views may remain hidden, they exert a "strong influence on educational policy and practice." Presumably, play is replaced by other means of learning that are deemed more essential or effective for achieving the identified outcomes. This brings the discussion back to the need for stakeholders at all levels-research, policy, system and school-to contribute to the collective decision-making about the outcomes they are pursuing, how to best facilitate those outcomes within the different contexts of the education system and how to reliably measure those outcomes.

\section{Challenge 4: A Division Between the Policy Environment and the Communities of Implementation}

The push for holistic child development through greater access to quality learning through play within our education systems is evident (Queensland Government, n.d.; Scottish Government, 2013; Zhao, 2015). However, the challenge of translating policy into practice is well recognized. Hargreaves (2010) observed, "seeds travel better than ripened fruit" (p. 115) and proposed that a more promising path may be to encourage policy principles to be interpreted among and between the communities of practice that will be charged with putting those principles into practice. Yet the division amongst these different communities of practice (preschool and school), coupled with a lack of clearly conceptualized "seeds" relating to the principles of learning through play, inhibit the successful implementation of quality learning through play within the school context.

Connecting the concept of learning through play with pedagogies familiar within the school context offers a step toward greater clarity about how learning through play might be implemented at school. Rather than disregarding the issue of context and the impact that it may have on the implementation of learning through play, Parker and Thomsen (2019) offered a bridge to connect the school context with the concept of play-based learning. These efforts support the realization of the key policy message found in the OECD's study Starting Strong V: Transitions from Early Childhood Education and Care to Primary Education (2017), that "schools [should] be ready for 
children, not children ready for school" (p. 16). Similarly, the characteristics of learning through play described by Zosh et al. (2017) help to more clearly define the concept in a way that brings in the experience of the student, and the description of holistic skills used by Parker and Thomsen (2019) defines the expanded goals for learning that might be supported by quality play experiences. At present, these efforts to clearly describe what is meant by learning through play within the context of early years education remain at the level of loosely connected ideas rather than interconnected elements that are the fundamental "seeds" of implementing quality learning through play. Similarly, Perkins and Reese (2014) argued that a key factor in sustainable and successful change initiatives is the existence of a quality framework that "provides teachers with a common perspective and language while allowing adaptation to different subjects, levels, and students" (p. 42). Importantly, these frameworks are not rigid directives that are imposed on teachers but remain flexible and adaptable to fit the individual context. In this way, the framework provides a tool to bring people together around a common goal or vision, while inviting active input from those involved in the implementation.

\section{A FRAMEWORK FOR LEARNING THROUGH PLAY AT SCHOOL}

Parker and Thomsen (2019) mapped the landscape of playful pedagogies and in doing so confirmed the characteristics of play as relevant and useful within primary school settings. They described the impact of playful pedagogies on learning outcomes, and explored design and facilitation features. Their work provides a theoretical foundation on which to build a framework to explore quality in learning through play. This framework could be used by all education stakeholders, including practitioners, to establish a common language and a consistent set of principles regarding play, learning, and quality in school education contexts. This is currently missing from the landscape of education research, policy, and practice, and is a significant barrier to understanding and uptake of playful pedagogies.

When education stakeholders proceed from a common understanding about play and learning, evidence about current practice can be gathered and quality assessed. It is argued that there are four key dimensions of quality learning through play: the learning outcomes, the play experience, the design, and the facilitation. These dimensions are presented in Figure 2. The relationships between them are signified with arrows to show how and where the elements are interconnected and intersect, and to remind the user of their relationship to each other. Each dimension is discussed, examples provided, and key guiding questions are offered for schools and systems to consider for planning next steps.

\section{STUDENT EXPERIENCE}

The framework incorporates the child's experience as a component of equal importance to the other three. This perspective aligns with principles articulated in international doctrine about the child's right to participate and be heard (United Nations Human Rights, 1989), to be recognized as capable (Haßler et al., 2015; National Association for the Education of Young Children [NAEYC], 2020), and to make choices about their learning (Fullan and Langworthy, 2014). Student experience is a unique feature of the framework and a positive step toward seeing learning through students' eyes; understanding what learning feels and looks like to them. This is a much needed and often missing piece of the quality teaching and learning puzzle, particularly in primary and secondary school (Hattie, 2009).

Implementing playful pedagogies requires schools and systems to consider how the student will experience learning as playful. The five characteristics of learning through play and the notion of student agency are useful organizing themes to support teachers' thinking in relation to this dimension. How a child experiences a playful learning activity could be considered in the activity design and measured in formative and summative ways. For example, Fitch and Hulgin (2008) recorded the student experience by observing that students asked to continue learning using their collaborative approach. Collecting data on children's experience of the emotions they felt, both positive and negative, and how they rate the challenge is important to understanding how children experience learning through play.

Embedding the characteristics of play in activities and lessons requires schools and systems to see the experience through the eyes of the learner rather than taking the perspective of the teacher. Key guiding questions that underpin student experience and quality learning through play include:

- What do systems, schools, school leaders and teachers understand about the characteristics of playful learning, and the playful pedagogies that might provide opportunities for such experience?

- How do systems and school communities including leaders support playful pedagogies, that is, approaches that emphasize active engagement in learning, student agency over their learning, learning that is meaningful to the individual and positive social interactions that contribute to learning?

\section{LEARNING OUTCOMES}

Successfully implementing playful pedagogies involves planning for intended learning outcomes. As discussed above, learning via playful pedagogies is understood in the broadest sense to refer to educating the whole child; fostering a range of skills and understandings. The focus on the wholechild development is a key distinguishing feature of learning through play when compared with other less-playful educational approaches regarding outcomes (Allee-Herndon and Roberts, 2020). All learning gains made by children are valued when learning through play, be they social, emotional, physical, cognitive or creative. However, it is important to carefully consider the suitability of impact measurement and assessment 


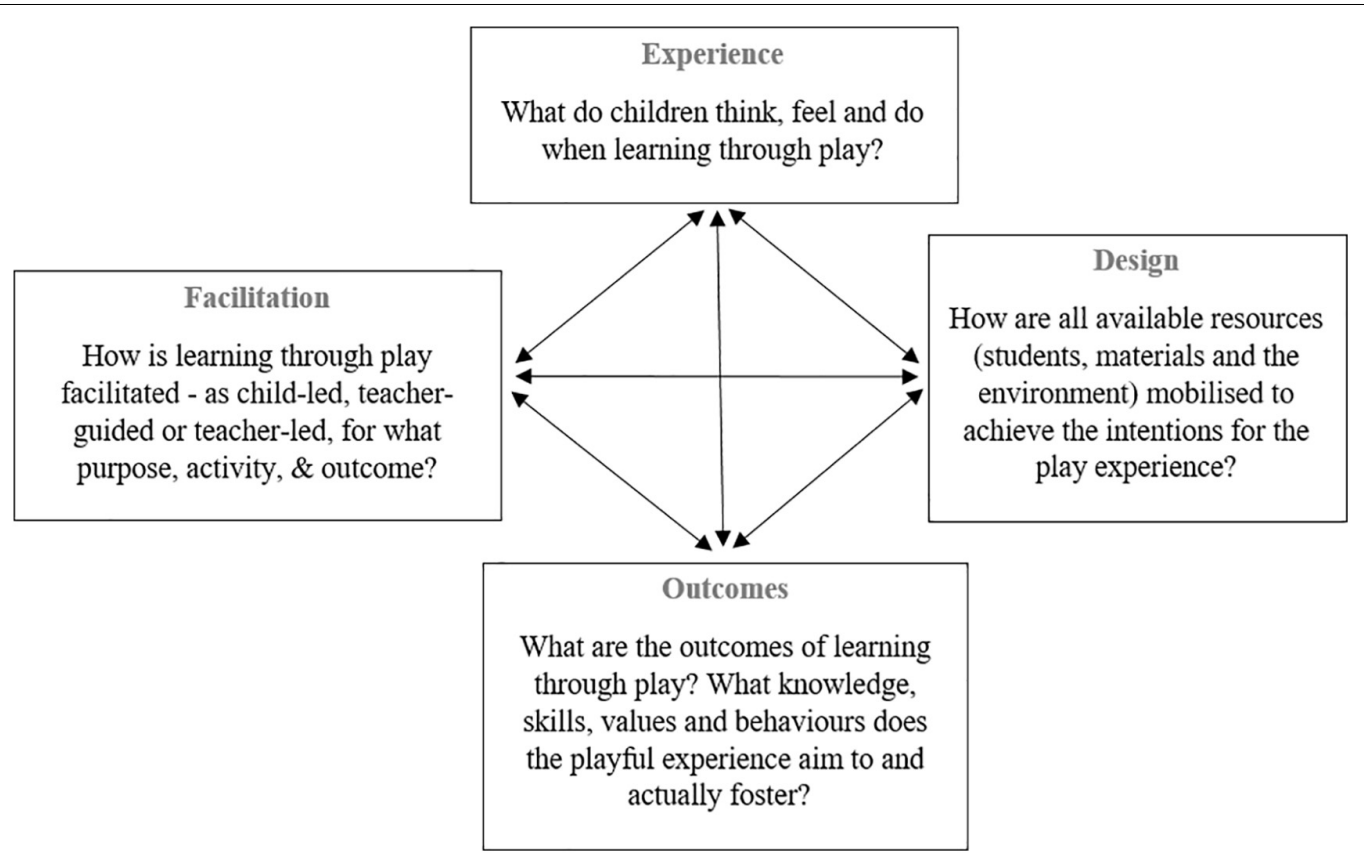

FIGURE 2 | Framework for quality learning through play at school.

tools to capture holistic skills. For example, Block et al. (2012) found no statistically significant difference between program and comparison schools participating in a structured cooking and gardening program using standardized quantitative measures of child wellbeing and attendance. However, interviews, observations and focus groups revealed the program as enjoyable with a positive impact on student engagement, confidence, and social connections at school and beyond. In the classroom, Barron and Darling-Hammond (2010) point to performance tasks as key to measuring the broad range of skills gained via inquiry-based learning.

Key guiding questions about play and learning outcomes include:

- How are teachers supported to connect related skills and concepts within the curriculum?

- How are teachers supported to identify individual levels of development and targeted goals for learning?

- To what extent are a range of holistic learning outcomes included and connected within the curriculum?

- To what extent is deep learning possible?

- To what extent can the curriculum be differentiated to cater for the range of ability levels within a classroom?

- Does the curriculum emphasize depth over breadth in learning, take a developmental view of learning and value a range of learning outcomes?

\section{FACILITATION}

It remains true that even the most thoughtfully designed learning experience can fail to achieve the intended outcomes if teachers are unable to effectively facilitate playful learning in the classroom. Skillful facilitation of learning through play is a complex process that requires a blend of teacherguided, student-led, and teacher-directed practices. This provides students with the guidance and scaffolding needed to support learning, while also supporting student agency and autonomy in their learning (Weisberg et al., 2016). While elements of facilitation may be planned during the design process, effective facilitation will inevitably involve skillful monitoring during the experience, adjustments in response to emerging needs and continuous assessment of student learning within the experience. For example, Hotulainen et al. (2016) described their enriched discovery learning program designed to foster first graders' thinking skills as featuring strong teacher-guidance. Teachers described the rules of the card game, provided scaffolded instruction where needed, and at the end of each lesson, facilitated a reflective discussion with children on what was difficult and how they overcame challenges.

Key guiding questions to answer regarding learning through play and facilitation include:

- How do teachers and schools ensure opportunities are provided for a range of facilitation types when children learn through play, and for what activity, outcome and purpose?

- To what extent are teachers empowered and equipped by schools, leaders and systems to differentiate within lessons to respond to individual learning needs by balancing instruction with guidance and open-ended inquiry?

- How are teachers supported to implement a range of formative assessment strategies and use the evidence 
gathered to inform their facilitation of learning with the lesson?

\section{DESIGN}

The design of the learning experience brings together the intentions for learning and experience of play. The key concern is how to make use of all available resources (students, materials, teacher/s and the learning environment) to best achieve the intentions for the learning experience. For example, Marshall (2017) described two key design features of the Montessori educational method as the learning materials and children's selfdirected engagement with them. Sensory materials such as toys, utensils are tools are integral to the Montessori classroom for the purposes of preparing the child for independent living, and building fine and gross motor skills. Children's self-directed engagement with materials has the twofold purpose of providing useful information to the teacher observer, and also supporting the child's ability to focus (Marshall, 2017) and develop selfcontrol Gray, 2011). Features of playful designs are activities and questions that are relevant and meaningful for children in that they integrate concepts and skills from the curriculum with children's interests and experiences. Key guiding questions regarding design and learning through play include:

- How can children and teachers access and/or leverage a wide range of available resources and a physical learning environment inside and outside school that is conducive to playful learning?

- Can teachers access and establish dialog with supportive networks within the school and community?

\section{DISCUSSION}

A framework for play and learning was created to progress research connecting policy and practice by creating continuity between the early years learning contexts and implementation in schools. This section includes a discussion of how well the framework achieves these aims. The framework is underpinned by definitional statements based on the science of learning, relevant child development theory, the role of the child and adult, and existing high impact teaching strategies. These statements give meaning and intent to framework elements, making them applicable to the school learning context.

The Framework for Quality LTP (Learning through Play) offers a basic structure to think about, understand, apply, and evaluate learning through play and playful pedagogies. Educational stakeholders often proceed from an implied understanding of play, learning, and the value of both. Yet beliefs and understandings about play and learning are as diverse as the experiences upon which these beliefs are based. The framework makes explicit what is meant by these terms, and does so in ways that bridge dichotomous representations which have inhibited progress and understanding to date (Furtak et al., 2016). In doing so, the framework creates a common language around learning through play and playful pedagogies to enable "collective sense making," where all those responsible for developing, designing, applying, and evaluating playful pedagogies understand them in the same way.

The Framework for Quality LTP could potentially facilitate better connections between policy and practice. The early years policy and practice disconnect is widely acknowledged and documented. Early years policy is often informed by evidence about the value of child-centered playful pedagogical approaches in the first years of school (Queensland Government, n.d.; Kaput, 2018), yet this policy discourse does not always align with and therefore travel across into school policy contexts. The disconnect extends to and is reinforced by the institutions and departments that support education for children aged zero to eight, with preservice education courses for preschool teachers and primary school teachers offered and taught separately. Further, educational research communities are organized into different groups depending on their focus on preschool or school teaching and learning. The position titles of those who facilitate learning in these contexts are usually distinct, and there are differing perceptions held about the value, contribution and professionalism of these roles within the education sector (Harwood et al., 2013). These divisions do children no favors as they prevent implementation of a cohesive and consistent educational offering for those aged zero to eight and beyond. The Framework for Quality LTP was designed incorporating empirical evidence, child development theories and effective teaching research across preschool and school contexts. It utilizes a definition which is broadly relevant to the early years and is based on current pedagogical practice in schools. It could reasonably be picked up by any school or system wishing to understand, apply or evaluate the quality of their playful practice.

The Framework for Quality LTP has the potential to empower teachers as agents of change by establishing a common understanding around playful pedagogies, impact and facilitation. Play has been used in the classroom as a reward, an opportunity for teachers to undertake administration, or to occupy children while a single child receives focused attention (Gronlund, 2010). Teachers are understandably skeptical about adopting playful pedagogies without a clear understanding of "the how and why" (Martlew et al., 2011). The Framework for Quality LTP addresses some fundamental questions posed by teachers about the value and impact of playful pedagogies, such as their role as an active facilitator, and how playful learning aligns with the curriculum, and is not devoid of structure.

For school communities to support playful pedagogies they must understand what is meant by play and learning, the roles and responsibilities of child and teacher, and the benefits for learning. The Framework for Quality LTP offers a clear and consistent language around play and learning that aligns with the expectations of school communities around evidence of learning and the teacher's role as facilitator. It provides a consistent language to communicate to school communities the role and benefits of playful pedagogies as legitimate vehicles for learning.

A lack of consensus on a definition and the core components of learning through play at school means it is not currently possible to develop instruments to measure the impact. The Framework for Quality LTP provides the opportunity to develop 
the research base and the type of instruments required to effectively measure playful learning, for both research purposes and formative and summative assessment. These include "performance assessments, and portfolio evaluation that apply learning to real problems of practice" (Darling-Hammond, 2006, p. 6). However, there are critical steps in the research process required to determine the validity of the framework across different contexts.

A framework based on constructivist learning theories is useful as it acknowledges the reality of classroom teaching practice-that these pedagogies, while conceptualized in isolation, are often referred to interchangeably (Friesen and Scott, 2013), as overlapping (Barron and Darling-Hammond, 2010), or applied in combination to meet all learners needs (Goldstein, 2016). Assessment and evaluative tools exist for specific pedagogical approaches such as project-based learning. However, it is challenging to assess a combined approach, for example, an active inquiry-based experiential learning approach. Comparing approaches has limited usefulness (Cattaneo, 2017), but an overarching framework offers the potential to create consistent evaluative tools to gather useful data about the efficacy of combined playful approaches.

\section{Future Directions}

The evidence that play supports learning is considerable. Moreover, understanding of learning has greatly expanded over the last few decades to include creative thinking, problem solving and socio-emotional learning as essential skills. This paper illuminates playful pedagogies and their potential to support schools and systems to catch up with advances in education research and learning theories. The Framework for Quality LTP holds the promise of a common collective language and dialog about play and learning to further the field and enhance quality. Other frameworks or rubrics may be needed, including those that measure the progress made by both teachers and students. When systems or schools commence a process of review of evaluation to support implementation of playful pedagogies, different stakeholders will be situated at different points at the

\section{REFERENCES}

Alfieri, L., Brooks, P. J., Aldrich, N. J., and Tenenbaum, H. R. (2011). Does discovery-based instruction enhance learning?. J. Educ. Psychol. 103, 1-18. doi: $10.1037 / \mathrm{a} 0021017$

Allee-Herndon, K. A., and Roberts, S. K. (2020). The Power of Purposeful Play in Primary Grades: adjusting Pedagogy for Children's Needs and Academic Gains. J. Educ. 201, 54-63.

Barblett, L. (2010). Why play-based learning?. Every Child 16, 4-5.

Barron, B., and Darling-Hammond, L. (2010). "Prospects and challenges for inquiry-based approaches to learning," in The nature of learning: Using research to inspire practice, eds H. Dumont, D. Istance, and F. Benavides (Paris: OECD Publishing), 199-225. doi: 10.1787/9789264086487-11-en

Block, K., Gibbs, L., Staiger, P. K., Gold, L., Johnson, B., Macfarlane, S., et al. (2012). Growing community: the impact of the Stephanie Alexander Kitchen Garden Program on the social and learning environment in primary schools. Health Educ. Behav. 39, 419-432. doi: 10.1177/1090198111422937

Bruner, J. S. (1961). The act of discovery. Harv. Educ. Rev. 31, 21-32. doi: 10.1016/ s0260-6917(97)80004-4 start and along the path, and these points and their associated characteristics can be described. For this reason, it might be helpful to define the student experience of learning as aiming to equip students with the confidence and agency to drive their own learning through the life span. Further, this thinking could be extended to describe three levels of progression within this category as follows:

- Student experiences are passive, following standards with no clear commitment or discernible expression of interest from the learner.

- Student experiences are active, with opportunity to adjust approaches to own interests with greater focus and greater understanding.

- Student experiences are self-driven with the confidence to try out new projects and apply their knowledge and skills to new situations.

Similarly, when teachers seek to employ playful pedagogies in the classroom, there are various identifiable points along the learning journey, characterized as three levels:

- Facilitation is applied with one instructional strategy without consideration for individual learner needs and context.

- Facilitation is needs-based with consideration for the individual student.

- Facilitation is adaptable and responsive to the context of the individual and classroom environment.

Further research would be valuable to extrapolate these levels and test them in different contexts with different classroom cohorts, and to develop common learning progressions for students and teachers regarding learning through play.

\section{AUTHOR CONTRIBUTIONS}

All authors listed have made a substantial, direct, and intellectual contribution to the work, and approved it for publication.

Bubikova-Moan, J., Hanne Næss, H., and Wollscheid, S. (2019). "ECE Teachers' views on play-based learning: a systematic review. Eur. Early Child. Educ. Res. J. 27, 776-800. doi: 10.1080/1350293X.2019.167 8717

Burke, L. A., and Williams, J. M. (2012). The impact of a thinking skills intervention on children's concepts of intelligence. Think. Skills Creat. 7, 145-152. doi: 10. 1016/j.tsc.2012.01.001

Castano, C. (2008). Socio-scientific discussions as a way to improve the comprehension of science and the understanding of the interrelation between species and the environment. Res. Sci. Educ. 38, 565-587. doi: 10.1007/s11165007-9064-7

Cattaneo, K. H. (2017). Telling active learning pedagogies apart: from theory to practice. J. New Approaches Educ. Res. 6, 144-152. doi: 10.7821/naer.2017.7.237

Cheng, R. W. Y., Lam, S. F., and Chan, J. C. Y. (2008). When high achievers and low achievers work in the same group: the roles of group heterogeneity and processes in project-based learning. Br. J. Educ. Psychol. 78, 205-221. doi: $10.1348 / 000709907 X 218160$

Darling-Hammond, L. (2006). Constructing 21st-century teacher education. J. Teach. Educ. 57, 300-314. doi: 10.1177/0022487105285962 
Davison, L., Galbraith, I., and McQueen, M. (2008). Cooperative learning: a partnership between an EPS and a school. Educ. Psychol. Pract. 24, 307-317. doi: 10.1080/02667360802488740

Dean, D. Jr., and Kuhn, D. (2007). Direct instruction vs. discovery: the long view. Sci. Educ. 91, 384-397. doi: 10.1002/sce.20194

DeLuca, C., and Hughes, S. (2014). Assessment in early primary education: an empirical study of five school contexts. J. Res. Child. Educ. 28, 441-460. doi: 10.1080/02568543.2014.944722

Department of Education and Training (2016). Victorian Early Years Learning and Development Framework (VEYLDF): For all children from birth to eight years. Available online at: https://www.education.vic.gov.au/Documents/childhood/ providers/edcare/veyldframework.pdf (accessed July, 2021).

Dewey, J. (1910). How we think. Boston: D.C. Heath\& Co Publishers. Retrieved from https://openlibrary.org/books/OL7236952M/How_we_think.

Di Mauro, M. F., and Furman, M. (2016). Impact of an inquiry unit on grade 4 students' science learning. Int. J. Sci. Educ. 38, 2239-2258. doi: 10.1080/ 09500693.2016.1234085

Dilkes, J., Cunningham, C., and Gray, J. (2014). The New Australian Curriculum, Teachers and Change Fatigue. Aust. J. Teach. Educ. 39, 45-64. doi: 10.1089/ jayao.2011.0006

Dinham, S. (2017). The lack of an evidence base for teaching and learning?: fads, myths, legends, ideology and wishful thinking. Prof. Voice 11, 17-25.

Ernst, J. R., and Reynolds, A. J. (2021). Preschool instructional approaches and age 35 health and well-being. Prev. Med. Rep. 23:101498. doi: 10.1016/j.pmedr.2021. 101498

Fantuzzo, J. W., and Hampton, V. R. (2000). "Penn interactive peer play scale: A parent and teacher rating system for young children," in Play Diagnosis and Assessment, 2nd Edn, eds K. Gitlin-Weiner, A. Sandgrund, and C. Schaefer (Hoboken: John Wiley), 599-620.

Fisher, K., Hirsh-Pasek, K., Golinkoff, R. M., Singer, D. G., and Berk, L. (2010). "Playing around in school: Implications for Learning and Education Policy," in The Oxford Handbook of the Development of Play, eds P. Nathan and A. D. Pelligrini (Oxford: Oxford University Press), doi: 10.1093/oxfordhb/ 9780195393002.001 .0001

Fitch, E. F., and Hulgin, K. M. (2008). Achieving inclusion through CLAD: collaborative Learning Assessment through Dialogue. Int. J. Incl. Educ. 12, 423-439. doi: 10.1080/13603110601121453

Foundation for Young Australians [FYA] (2017). The New Work Order. Ensuring young Australians have skills and experience for the jobs of the future, not the past. Melbourne: FYA.

Friesen, S., and Scott, D. (2013). Inquiry-based learning?: A review of the research literature. Alberta Ministry of Education. Available online at: http://galileo.org/ focus-on-inquiry-lit-review.pdf (accessed July, 2021).

Fullan, M., and Langworthy, M. (2014). A Rich Seam: How New Pedagogies Find Deep Learning. London: Pearson.

Furtak, E. M., Seidel, T., Iverson, H., and Briggs, D. C. (2016). Experimental and quasi-experimental studies of inquiry-based science teaching: a meta- analysis. Rev. Educ. Res. 82, 300-329. doi: 10.3102/003465431245 7206

Goldstein, O. (2016). A project-based learning approach to teaching physics for pre-service elementary school teacher education students. Cogent Educ. 3:1200833. doi: 10.1080/2331186X.2016.1200833

Gordon, N. S., Burke, S., Akil, H., Watson, S. J., and Panksepp, J. (2003). Sociallyinduced brain "fertilization": play promotes brain derived neurotrophic factor transcription in the amygdala and dorsolateral frontal cortex in juvenile rats. Neurosci. Lett. 341, 17-20. doi: 10.1016/s0304-3940(03)00158-7

Gray, P. (2011). The Decline of Play and the Rise of Psychopathology in Children and Adolescents. Am. J. Play 3, 443-463.

Gronlund, G. (2010). Developmentally Appropriate Play: Guiding Young Children to a Higher Level. St. Paul: Red Leaf Press.

Hargreaves, A. (2010). "Change from without: Lessons from other countries, systems, and sectors," in Springer International Handbooks of Education: Second international handbook of educational change, eds A. Hargreaves, A. Lieberman, M. Fullan, and D. Hopkins (Berlin: Springer), 105-117. doi: 10.1007/978-90481-2660-6 6

Harwood, D., Klopper, A., Osanyin, A., and Vanderlee, M.-L. (2013). 'It's more than care': early childhood educators' concepts of professionalism. Early Years 33, 4-17. doi: 10.1080/09575146.2012.667394
Hattie, J. (2009). Visible learning: A Synthesis of Over 800 Meta-Analyses Relating to Achievement. Oxfordshire: Routledge. doi: 10.4324/9780203887332

Haßler, B., Hennessy, S., Cross, A., Chileshe, E., and Machiko, B. (2015). Schoolbased professional development in a developing context: lessons learnt from a case study in Zambia. Prof. Dev. Educ. 41, 806-825. doi: 10.1080/19415257. 2014.938355

Hill, H. (2006). "Language matters: How characteristics of language complicate policy implementation," in New directions in education policy implementation: Confronting complexity, ed. M. Honig (Albany: State University of New York Press).

Hixson, N., Ravitz, J., and Whisman, A. (2012). Extended professional development in project-based learning: Impacts on 21st century teaching and student achievement. Charleston: West Virginia Department of Education.

Hmelo-Silver, C., Duncan, R., and Chinn, C. (2007). Scaffolding and achievement in problem-based and inquiry based learning: a response to Kirschner, Sweller, and Clark (2006). Educ. Psychol. 42, 99-107. doi: 10.1080/00461520701263368

Hotulainen, R., Mononen, R., and Aunio, P. (2016). Thinking skills intervention for low-achieving first graders. Eur. J. Spec. Needs Educ. 31, 360-375. doi: 10.1080/08856257.2016.1141541

Howard, J. (2010). Early years practitioners' perceptions of play: an exploration of theoretical understanding, planning and involvement, confidence and barriers to practice. Educ. Child Psychol. 27, 91-102.

Hunzicker, J., and Lukowiak, T. (2012). Effective Teaching and Student Engagement in the College Classroom: using the Instructional Practices Inventory (IPI) as a Tool for Peer Observation and Self-Reflection. J. Excell. Coll. Teach. 23, 99-132.

Hushman, C. J., and Marley, S. C. (2015). Guided instruction improves elementary student learning and self-efficacy in science. J. Educ. Res. 108, 371-381. doi: 10.1080/00220671.2014.899958

Irwin, L. G., Siddiqi, A., and Hertzman, C. (2007). Early child development: A powerful equalizer: Final report. Available online at: http://whqlibdoc.who.int/ hq/2007/a91213.pdf?ua=1 (accessed July, 2021).

Jay, J. A., and Knaus, M. (2018). Embedding play-based learning into junior primary (Year 1 and 2) curriculum in WA. Aust. J. Teach. Educ. 43, 112-126. doi: 10.14221 /ajte.2018v43n1.7

Johnson, D. W., and Johnson, R. T. (1991). Learning Together and Alone: Cooperative, Competitive, and Individualistic Learning, 3rd Edn. Boston: Allyn and Bacon.

Kaput, K. (2018). Evidence for Student-Centered Learning. Minnesota: Education Evolving.

Kirschner, P. A., Sweller, J., and Clark, R. E. (2006). Why minimal guidance during instruction does not work: an analysis of the failure of constructivist, problembased, experiential and inquiry-based teaching. Educ. Psychol. 41, 75-86. doi: 10.1207/s15326985ep4102_1

Laevers, F. (2000). Forward to basics! Deep-level-learning and the experiential approach. Early Years 20, 20-29. doi: 10.1080/0957514000200203

Louis, K. S. (2010). "Better schools through better knowledge? New understanding, new uncertainty," in Springer International Handbooks of Education: Second international handbook of educational change, eds A. Hargreaves, A. Lieberman, M. Fullan, and D. Hopkins (Berlin: Springer), 105-117. doi: 10.1007/978-90481-2660-6_1

Marbina, L., Church, A., and Tayler, C. (2011). Victorian early years learning and development framework: Evidence paper: Practice principle 6: Integrated teaching and learning approaches. Parkville: University of Melbourne.

Marshall, C. (2017). Montessori education: a review of the evidence base. NPJ Sci. Learn. 2:11. doi: 10.1038/s41539-017-0012-7

Martlew, J., Stephen, C., and Ellis, J. (2011). Play in the primary school classroom? The experience of teachers supporting children's learning through a new pedagogy. Early Years 31, 71-83. doi: 10.1371/journal.pone.0222447

Mastrangelo, S. (2009). Harnessing the power of play. Teach. Except. Child. 42, 34-44. doi: 10.1177/004005990904200104

McAloney, K., and Stagnitti, K. (2009). Pretend Play and Social Play: the Concurrent Validity of the Child-Initiated Pretend Play Assessment. Int. J. Play Ther. 18, 99-113. doi: 10.1111/j.1440-1630.2008.00761.x

McBride, A. M., Chung, S., and Robertson, A. (2016). Preventing academic disengagement through a middle school-based social and emotional learning program. J. Exp. Educ. 39, 370-385. doi: 10.1177/10538259166 68901 
Miller, E., and Almon, J. (2009). Crisis in the Kindergarten: Why Children Need to Play in School. Maryland: Alliance for Childhood.

Moss, P. (2013). Early Childhood and Compulsory Education: Reconceptualising the Relationship. London: Routledge.

National Association for the Education of Young Children [NAEYC] (2020). Developmentally appropriate practice: A position statement of the National Association for the Education of Young Children. Washington: NAEYC.

Nicholson, P., and Hendry, H. (2020). A pedagogical meeting place or a problem space? Extending play-based pedagogy in Year One. Education 50, 184-196. doi: $10.1080 / 03004279.2020 .1840608$

Nilsson, M., Ferholt, B., and Lecusay, R. (2018). "The Playing-Exploring Child": reconceptualizing the Relationship between Play and Learning in Early Childhood Education. Contemp. Issues Early Child. 19, 231-245. doi: 10.1177/ 1463949117710800

OECD (2017). Starting Strong V: Transitions from Early Childhood Education and Care to Primary Education. Paris: OECD. doi: 10.1787/9789264276253-en

OECD (2018). Future of Education and Skills: Education 2030. Paris: OECD.

Oxford University Press (2020). Definition of play. In Lexico UK dictionary. Available online at: https://www.lexico.com/definition/play (accessed July, 2021).

Parker, R., and Thomsen, B. S. (2019). Learning through play at school: A study of playful integrated pedagogies that foster children's holistic skills development in the primary school classroom. Billund: LEGO Foundation.

Pellis, S. M., Pellis, V. C., and Himmler, B. T. (2014). How play makes for a more adaptable brain: a comparative and neural perspective. Am. J. Play 7:73.

Perkins, D., and Reese, J. (2014). When change has legs. Educ. Leadersh. 71, 42-47. doi: 10.1007/s00268-016-3706-8

Priestley, M. (2011). Schools, teachers, and curriculum change: a balancing act? J. Educ. Chang. 12, 1-23. doi: 10.1007/s10833-010-9140-z

Purpura, D., Baroody, A., Eiland, M., and Reid, E. (2016). Fostering first graders' reasoning strategies with basic sums: the value of guided instruction. Elem. Sch. J. 117, 72-100. doi: 10.1086/687809

Pyle, A., and Danniels, E. (2016). A continuum of play-based learning: the role of the teacher in play-based pedagogy and the fear of hijacking play. Early Educ. Dev. 23, 274-289. doi: 10.1080/10409289.2016.1220771

Pyle, A., DeLuca, C., and Danniels, E. (2017). A Scoping Review of Research on Play-Based Pedagogies in Kindergarten Education. Rev. Educ. 5, 311-351. doi: $10.1002 / \mathrm{rev} 3.3097$

Pyle, A., DeLuca, C., Danniels, E., and Wickstrom, H. (2020). A Model for Assessment in Play-Based Kindergarten Education. Am. Educ. Res. J. 57, 22512292. doi: $10.3102 / 0002831220908800$

Queensland Government (n.d.). Foundation Paper: Age appropriate pedagogies for the early years of schooling. Available online at: https://earlychildhood.qld.gov. au/earlyYears/Documents/foundation-paper.pdf (accessed July, 2021).

Roskos, K. A., Christie, J. F., Widman, S., and Holding, A. (2010). Three decades in: priming for meta-analysis in play-literacy research. J. Early Child. Lit. 10, 55-96. doi: 10.3945/ajen.110.000547

Schwartz, M. S., Sadler, P. M., Sonnert, G., and Tai, R. H. (2009). Depth versus breadth: how content coverage in high school science courses relates to later success in college science coursework. Sci. Educ. 93, 798-826. doi: 10.1002/sce. 20328

Scottish Government (2013). Play strategy for Scotland: Our vision. Available online at: https://www2.gov.scot/resource/0042/00425722.pdf (accessed July, 2021).

Sinnema, C., Sewell, A., and Milligan, A. (2011). Evidence-informed collaborative inquiry for improving teaching and learning. Asia Pac. J. Teach. Educ. 39, 247-261. doi: 10.1080/1359866X.2011.597050

Smith, S. (2015). Playing to engage: Fostering engagement for children and teachers in low socioeconomic regions through science and mathematics play-based learning. Ph.D. thesis. Fremantle: University of Notre Dame Australia.

Tan, J. C. L., and Chapman, A. (2016). Project-Based Learning for AcademicallyAble Students: Hwa Chong Institution in Singapore. Netherlands: Sense Publishers.

UNESCO (2016). Global Education Monitoring Report: Education for people and planet: creating sustainable futures for all (ED-2016/WS/33/Rev). Paris: UNESCO digital library.

UNESCO (n.d.). Viewpoint: How to foster global citizenship through education. Paris: UNESCO.
United Nations Human Rights (1989). Convention on the Rights of the Child. Geneva: United Nations Human Rights.

van der Heijden, H. R. M. A., Beijaard, D., Geldens, J. J. M., and Popeijus, H. L. (2018). Understanding teachers as change agents: an investigation of primary school teachers' self-perception. J. Educ. Chang. 19:347. doi: 10.1007/s10833018-9320-9

Verner, J., and Lay, W. H. (2010). "Invoking the $\mathrm{L}$ in the scholarship of teaching and learning," in Engaging Student Voices in the Study of Teaching and Learning, eds C. Werder and M. M. Otis (Sterling: Stylus).

Vincent-Lancrin, S., Jacotin, G., Urgel, J., Kar, S., and González-Sancho, C. (2017). Measuring Innovation in Education: A Journey to the Future. Paris: OECD.

Vygotsky, L. S. (1978). The Role of Play in Development. Mind in Society: Development of Higher Psychological Processes, eds M Cole, V. John-Steiner, S. Scribner., E. Souberman, Cambridge: Harvard University Press, 92-104. doi: $10.2307 /$ j.ctvjf9vz4.12.

Wall, S., Litjens, I., and Taguman, M. (2015). Pedagogy in early childhood education and care (ECEC): An international comparative study of approaches and policies: Research brief. London: Department for Education.

Watkins, D., and Biggs, J. B. (2001). "The paradox of the Chinese learner and beyond," in Teaching the Chinese learner: Psychological and pedagogical perspective, eds D. Watkins and J. B. Biggs (Hong Kong: Comparative Education Research Centre), 3-23. doi: 10.1007/978-90-481-38 40-1_1

Weisberg, D., Hirsh-Pasek, K., Golinkoff, R., Kittredge, A., and Klahr, D. (2016). Guided play: principles and Practice. Curr. Dir. Psychol. Sci. 25, 177-182. doi: 10.1177/096372141664 5512

Weisberg, D. S., Hirsh-Pasek, K., and Golinkoff, R. M. (2013). Guided play: where curricular goals meet a playful pedagogy. Mind Brain Educ. 7, 104-112. doi: $10.1111 / \mathrm{mbe} .12015$

Whitebread, D., Basilio, M., Kuvalja, M., and Verma, M. (2012). The Importance of Play. Belgium: Toy Industries of Europe.

Wing, L. A. (1995). Play is Not the Work of the Child: young Children's Perceptions of Work and Play. Early Child. Res. Q. 10:223. doi: 10.1016/j.chiabu.2019. 104088

Woodhead, M., and Moss, P. (eds) (2007). Early Childhood and Primary Education: Transitions in the Lives of Young Children. Early Childhood in Focus (2). Milton Keynes: Open University.

World Health Organization [WHO] (2020). Improving early childhood development: WHO guideline. Geneva: World Health Organization.

Zhao, Y. (2015). Lessons that matter: What should we learn from Asia? (Mitchell Institute policy paper no. 04/2015). Melbourne: Mitchell Institute for Health and Education Policy.

Zosh, J. M., Hirsh-Pasek, K., Hopkins, E. J., Jensen, H., Liu, C., Neale, D., et al. (2018). Accessing the Inaccessible: redefining Play as a Spectrum. Front. Psychol. 9:1124. doi: 10.3389/fpsyg.2018.01124

Zosh, J. M., Hopkins, E. J., Jensen, H., Liu, C., Neale, D., Hirsh-Pasek, K., et al. (2017). Learning through play: A review of the evidence. Denmark: LEGO Foundation.

Conflict of Interest: The authors declare that the research was conducted in the absence of any commercial or financial relationships that could be construed as a potential conflict of interest.

Publisher's Note: All claims expressed in this article are solely those of the authors and do not necessarily represent those of their affiliated organizations, or those of the publisher, the editors and the reviewers. Any product that may be evaluated in this article, or claim that may be made by its manufacturer, is not guaranteed or endorsed by the publisher.

Copyright (c) 2022 Parker, Thomsen and Berry. This is an open-access article distributed under the terms of the Creative Commons Attribution License (CC BY). The use, distribution or reproduction in other forums is permitted, provided the original author(s) and the copyright owner(s) are credited and that the original publication in this journal is cited, in accordance with accepted academic practice. No use, distribution or reproduction is permitted which does not comply with these terms. 